\title{
Flourishing during emerging adulthood from a gender perspective.
}

\section{De la Fuente, R., Parra, A., Sánchez-Queija, I., Lizaso, I}

\begin{abstract}
Flourishing is when an individual perceives that their life is going smoothly. It encompasses hedonic and eudaimonic aspects of well-being: feeling good and functioning well. The construct's correlation with indicators of adjustment and positive development makes it an attractive concept for assessing well-being. Emerging adulthood is a transitional period susceptible to numerous changes that can impact on flourishing. Using a gender-based approach in a sample of 1502 Spanish university students aged between 18 and 29 years, we examined the characteristics of emerging adults most associated with their flourishing. The study included perceived family income, variables related to developmental tasks inherent in this stage, variables that define the period, educational variables and social support variables. A clear distinction between male and female flourishing and its correlates was observed. Flourishing in females was significantly higher than in males. The study variables explained $46 \%$ of flourishing in male respondents and $16 \%$ in female respondents; the predictors of flourishing differed by gender. These gender differences are discussed, and the recommendation is made for future research to include other variables that successfully explain female flourishing and which shed light on the identified gender gap.
\end{abstract}

Keywords Flourishing - Well-being - Emerging Adulthood - Gender - Developmental Task - Positive Development - Social Support

Corresponding author: Sánchez-Queija, I. E-mail: queija@us.es 
De la Fuente, R., Sánchez-Queija, I., Parra, A., y Lizaso, I. (2019). Flourishing during

emerging adulthood from a gender perspective. Journal of Happiness Studies.

doi: 10.1007/s10902-019-00204-9. In press.

\section{Introduction}

Flourishing is a modern and key concept in the field of positive psychology (Huppert and So 2009; Seligman 2011), used for the first time by Corey Keyes in 2002 to describe high levels of well-being (Hone, Jarden, Schofield and Duncan 2014). The term flourishing refers to an individual's perception that their life is going smoothly. It is a combination of feeling good-traditionally known as hedonic or subjective well-being - and functioning well, which is classed as eudaimonic or psychosocial well-being (Huppert and So 2009, 2013; Keyes, Shmotkin and Ryff 2002; Ryff and Singer 1998).

The concept of flourishing encompasses a wide variety of components, such as purpose in life, positive relationships, engagement, competence, self-esteem, optimism and contributing to the well-being of others (Diener et al. 2010). Thus, flourishing represents a more comprehensive and inclusive concept than other measures of well-being such as self-esteem and life satisfaction. Although flourishing strongly correlates with these construct (Dogan, Totan, and Sapmaz 2013; Paradise and Kernis 2002), terms such as self-esteem, optimism and life satisfaction do not go far enough in describing the flourishing experience (Hupert and So 2013), nor should they be used interchangeably. For example, self-esteem represents a component that figures in most current conceptualisations of flourishing (Hone et al. 2014). However, flourishing goes beyond that. In other words, self-esteem does not mean assessing flourishing, and assessing flourishing involves looking at more than just self-esteem. Regarding the relationship between flourishing and life satisfaction, the latter concept has been defined as the global evaluation that a person makes of his or her life, examining the tangible aspects and thus reaching an evaluative judgement of general satisfaction (Lucas, Diener and Suh 1996). Huppert and So (2013) analysed the relationship between life satisfaction and flourishing. They found a positive correlation between both constructs, but a modest overlap (about half of the respondents with high flourishing had high life satisfaction, and only a third of those with high life satisfaction had high flourishing). Thus, they concluded that both concepts were clearly different because life satisfaction does not take into account the aspects of psychological functioning encompassed by the concept of flourishing.

High levels of flourishing are associated with a whole series of adjustment indicators, including effective learning, high productivity, strong creative skills, prosocial behaviour, good health and life expectancy (Dolan, Peasgood and White 2008; Huppert 2009; Huppert and So 2013; Lyubomirsky, Sheldon and Schkade 2005; Vázquez, Hervás, Rahona and Gómez 2009). Taking this into account, it is becoming increasingly more relevant to explore the characteristics of people who flourish and who do so especially during periods of transition. One such period is emerging adulthood, a time when personal options are being weighed up and there are plenty of paths to take to reach adulthood (Arnett 2000). Similarly, the variables that contribute to understanding the nuances of flourishing in males and females require attention. Although some studies have identified flourishing differences between both sexes (Keyes 2007; Keyes et al. 2002; Schotanus-Dijkstra et al. 2016), few have analysed it from a gender perspective. 
De la Fuente, R., Sánchez-Queija, I., Parra, A., y Lizaso, I. (2019). Flourishing during

emerging adulthood from a gender perspective. Journal of Happiness Studies.

doi: 10.1007/s10902-019-00204-9. In press.

Emerging adulthood is a developmental stage that has arisen in western countries as a result of social and economic changes in recent decades. It describes a period that begins in late adolescence and lasts well into the third decade of life (Arnett 2000). This stage is typical of technology-driven societies and is defined as an age of identity exploration, instability, self-focus, subjectively feeling in-between adolescence and adulthood, and a time that opens up new possibilities (Arnett 2007a).

Numerous studies have shown that, compared with adolescence, most young people experience improved well-being during emerging adulthood (Aseltine and Gore 1993; Gestsdottir et al. 2015), thus exhibiting a decrease in depressive symptoms and enhanced self-esteem (Arnett 2007b; Galambos, Barker and Krahn 2006; Orth and Robins 2014). However, the transition to adulthood is not without stressful factors that may exceed some young people's ability to cope. Because of the instability characteristic of this period (Arnett 2004), some emerging adults experience high levels of insecurity and serious mental health problems such as anxiety and depression (Padilla-Walker, Barry, Carroll, Madsen and Nelson 2008; Schulenberg and Zarrett 2006). Furthermore, the exploration component, which also characterises this stage, often involves engaging in risk-taking behaviours. These include the consumption of alcohol and other drugs, sexual risk behaviours, and the inappropriate use of pornography and video games (Bachman, Johnston, O’Malley and Schulenberg 1996; Leftkowitz and Gillen 2006; Padilla-Walker, Nelson, Carroll and Jensen 2010; Schulenberg, O’Malley, Bachman and Johnston 2000), all of which can impact negatively on flourishing.

Although continuity in well-being generally prevails across the transition (Schulenberg, Bryant and O'Malley 2004), these years can represent a turning point, whereby young people must take on the challenges and opportunities that come with new roles and social contexts, tackling new period-specific developmental tasks (Aseltine and Gore 1993; Petersen 1993; Schulenberg, Bryant and O’Malley 2004; Schulenberg, Maggs and O'Malley 2003; Schulenberg et al. 2000). Thus, some may find it difficult to adapt to adult roles. It is also possible that others may flourish through successful experiences prompted by new opportunities and transition-specific tasks (Schulenberg, Bryant and O’Malley 2004).

Many of the difficulties that may occur at this stage stem from a mismatch between the needs or wishes of young people relative to period-specific developmental tasks and the opportunities that the prevailing context creates (Schulenberg, Bryant and O’Malley 2004; Schulenberg and Zarrett 2006). It should be noted that Spain has the second highest youth unemployment rate in the EU, standing at $40.5 \%$ (Eurostat 2017a). The type of work available to this group is extremely precarious and a large number of highly-skilled young people are forced to emigrate (INJUVE 2016). This economic instability undoubtedly contributes to young people leaving home three years later than the European averagespecifically, males at 30.3 years and females at 28.3 years (Eurostat 2017c) - and the age at which young Spaniards have their first child is postponed until into their thirties (INJUVE 2016). This reality reflects a difficult developmental context for those moving through emerging adulthood, and undoubtedly provides an excellent framework for studying the characteristics of flourishing young people, even in this potentially hostile environment. 
De la Fuente, R., Sánchez-Queija, I., Parra, A., y Lizaso, I. (2019). Flourishing during

emerging adulthood from a gender perspective. Journal of Happiness Studies.

doi: 10.1007/s10902-019-00204-9. In press.

\subsection{Characteristics of flourishing young people}

\subsubsection{Sex and family purchasing power}

A substantial body of research has to date focused on the role that sociodemographic variables play in an individual's well-being (Diener, Lucas and Oishi 2018; Schotanus-Dijkstra et al. 2016). These studies report that sociodemographic variables explain between $8 \%$ and $20 \%$ of the well-being variance (Argyle 2001; DeNeve and Cooper 1998).

The results by gender are inconsistent (Batz and Tay 2018). On occasions, researchers have been unable to find any significant differences between male and female well-being (Waterman et al. 2010). However, other studies have proved successful, although these significant differences did not always follow the same pattern. Some studies have recently demonstrated that females flourish more than males (Schotanus-Dijkstra et al. 2016), whereas others conclude that males exhibit higher levels of flourishing than their female counterparts (Keyes 2007; Keyes, Shmotkin and Ryff 2002). Specifically, during emerging adulthood, Galambos et al. (2006) observed lower levels of self-esteem in females than in males at 18 years, but self-esteem in females rose at a faster rate from age 25 onwards (Galambos et al. 2006). Besides identifying whether levels of flourishing vary by sex, an interesting approach is to analyse whether the variables that predict male and female well-being are different in nature and, even if they are the same, whether they predict male and female well-being to varying degrees (Tesch-Römer, MotelKlingebiel and Tomasik 2008).

Regarding level of income, some research studies reveal that being financially solvent has a positive effect on the population and, in turn, on their level of well-being (Diener, Suh, Lucas and Smith 1999; Diener and Ryan 2009). However, studies such as that of Waterman et al. (2010), which involved college students, found no significant differences in psychosocial functioning relative to family income.

\subsubsection{Stage-specific developmental tasks and the defining characteristics of emerging adulthood}

The developmental tasks characteristic of emerging adulthood are having a job, being in a relationship, and leaving the family home and living independently (Havighurst 1952; Heckhausen 1999; Schulenberg, Bryant and O'Malley 2004). Regarding the first variable, having a job has shown to be positively associated with well-being (Diener, Suh, Lucas and Smith 1999; Diener and Ryan 2009; Ryff and Keyes 1995; Ryff and Singer 2008; Veenhoven, 1996, 2008). If we take into account that males more easily enter the labour market (Eurostat 2017b; INE 2018; Marosi and Velikonja 2013), the different job opportunity expectations of both sexes may mean that having a job or not differentially affects the level of flourishing exhibited by young males and females.

Research has also found that being in a stable, committed relationship promotes well-being and positive health (Braithwaite, Delevi and Fincham 2010; Roberson, Norona, Bishop and Welsh 2017). Studies including that of Lehnart, Neyer and Eccles (2010) found that not having a boyfriend or girlfriend during the teenage years has a more negative impact on self-esteem in boys than in girls. From this 
De la Fuente, R., Sánchez-Queija, I., Parra, A., y Lizaso, I. (2019). Flourishing during

emerging adulthood from a gender perspective. Journal of Happiness Studies.

doi: 10.1007/s10902-019-00204-9. In press.

perspective, being in a dating relationship could be more decisive for males than females in their flourishing.

Lastly, leaving home is accompanied by shifts in social and contextual roles that positively impact on emerging adults' health and well-being (Dubas and Petersen 1996; Tanner, Arnett and Leis 2008). The trend towards later home-leaving makes it difficult to achieve adult status and a feeling of independence, and can have consequences when it comes to redefining roles, thus impacting negatively on well-being (Kins and Beyers 2010). In this study, we ask whether achieving this developmental task would weigh differently on male and female well-being.

Regarding the variables that define emerging adulthood-identity exploration, experimentation/possibilities, self-focus, and feeling in-between - to date, and to our knowledge, there are no studies that analyse how it relates to flourishing and well-being across its numerous measures, and much less from a gender perspective. However, assuming the above line of argument, these variables may have a differential effect on flourishing in males and females.

1.1.3 The role of prioritising studies and academic performance

Emerging adults are largely students (OECD 2017). Various research has shown a relationship between flourishing and different indicators of academic success such as enhanced performance, academic commitment and motivation (Datu 2018; Seligman, Ernst, Gillham, Reivich and Linkins 2009). In this regard, O'Connor et al. (2011) found school adjustment to be a predictor of positive development during emerging adulthood.

Over fifty percent (58.5\%) of all graduates in Spain are female (MECD 2016). They devote more time and effort to their university studies (Navarro-Guzmán and Casero-Martínez 2012) and consider them a priority in their lives. These studies are a productive resource, an investment that will reap long-term benefits, and a tool that will help them climb the social ladder and attain gender equality (Alberdi, Escario and Matas 2000). A greater effort and commitment towards their studies could be a way for females to accomplish their goals in life, perhaps making the relationship between academic success and commitment and flourishing more important for females than for males during emerging adulthood.

\subsubsection{Perceived social support}

Several studies have demonstrated the importance of social support for psychological and subjective wellbeing and happiness in the long term (Caunt, Franklin, Brodaty and Brodaty 2012; Diener and Seligman 2002, 2004; Huppert 2009), especially during periods of transition such as emerging adulthood (Lee and Goldstein 2016). Specifically, peers and family members play a highly influential role in predicting wellbeing during these years (O'Connor et al. 2011). Positive peer relations predict a stable and high trajectory of well-being in individuals' lives (Schulenberg, Bryant and O'Malley 2004), and young people who receive family support feel a greater sense of self-esteem, optimism, positive affect and mental health (Thomas, Liu, Umberson and Suitor 2017). Furthermore, dating relationships during emerging 
De la Fuente, R., Sánchez-Queija, I., Parra, A., y Lizaso, I. (2019). Flourishing during

emerging adulthood from a gender perspective. Journal of Happiness Studies.

doi: 10.1007/s10902-019-00204-9. In press.

adulthood become more frequent and meaningful (Arnett 2015). As such, social support from this source, not surprisingly, gains importance for achieving well-being (Lee and Goldstein 2016) and for avoiding mental health problems (Howard Sharp et al. 2017).

There are no definitive data on the potential role that these three sources of support play in male and female well-being during emerging adulthood. Authors including Galambos et al. (2006), and more recently Lee and Goldstein (2016), concluded that these supports relate more to well-being in females than in males. However, O'Connor et al. (2011) found this relationship to be stronger among the male population.

Adopting a gender perspective, we examined the characteristics of emerging adults most associated with their flourishing. These were perceived family income; the resolution of core developmental tasks at this stage (having a job, being in a relationship, and living independently); specific variables that define emerging adulthood (identity exploration, experimentation/possibilities, self-focus, and feeling inbetween); educational variables (academic commitment and perceived performance); and social support variables (support from friends, family and dating partner). The study was conducted on a large sample of Spanish university students in order to identify which of the listed variables predict flourishing in emerging adulthood and if these variables differentially predict flourishing in males and females.

\section{Method}

\subsection{Participants}

The sample comprised 1502 university students; 747 were female $(65.2 \%)$ and 755 were male, aged between 18 and 29 years $(M=20.32$ and $S D=2.13)$. The participants were students at the University of Seville and the University of Basque Counry (Spain). Subjects were recruited by considering the representative distribution of the different subject areas (MECD 2015): Arts and Humanities (8.5\%), Social Sciences and Legal Studies (32.2\%), Engineering and Architecture (23.5\%), Health Sciences $(29.2 \%)$, and Sciences $(6.7 \%)$.

\subsection{Instruments}

Sociodemographic variables. Information was collected on sex (male or female), subject area being studied, and perceived level of family income. Perceived family income was measured using an ad hoc scale developed by the research team. Emerging adults were asked to rate their family's income level on a 3-point scale ranging from 1 (perception of serious economic difficulties) to 3 (perception of having a high enough income to live comfortably).

Markers of adulthood. These were being in a stable relationship or not, having a job or not at the time of study, and living at home or not with both or one parent.

Emerging Adulthood. We used the Spanish version of the Inventory of the Dimensions of Emerging Adulthood (Reifman, Arnett and Colwell 2007). This survey asks: "Is this period of your life a..." identity exploration ( $\alpha=.76$; e.g., "time of finding out who you are?"); experimentation/possibilities ( $\alpha=$ .69 , e.g., "time of many possibilities?"); self-focused ( $\alpha=.68$; e.g., "time of settling down?"); or feeling 
De la Fuente, R., Sánchez-Queija, I., Parra, A., y Lizaso, I. (2019). Flourishing during

emerging adulthood from a gender perspective. Journal of Happiness Studies.

doi: 10.1007/s10902-019-00204-9. In press.

'in-between' ( $\alpha=.55$; e.g., "time of feeling adult in some ways but not others?"). All items are responded to on a Likert scale ranging from 1 (Strongly disagree) to 4 (Strongly agree).

Flourishing. We used the Spanish version (De la Fuente, Parra and Sánchez-Queija 2017) of the Flourishing Scale (Diener et al. 2010). This scale comprises eight items (e.g., "I lead a purposeful and meaningful life") measured on a 7-point Likert-type scale ranging from 1 (Strongly disagree) to 7 (Strongly agree). In Diener et al.'s (2010) original study, this scale obtained an alpha of .87 and was found to be unifactorial. Subsequent studies such as the Spanish validations, using a process which tests for factorial invariance (De la Fuente et al. 2017) or comparing normative samples of students and patients with chronic pain (Ramírez-Maestre et al. 2017), also confirmed the scale's unidimensionality and its reliability above .80 . In the present study, a total alpha of .81 was obtained; specifically, .82 for males and .81 for females.

Educational Context. Two items corresponding to perceived academic performance and prioritising studies were added: "I achieve high grades in relation to my studies" and "I regard my academic work as top priority". Both items are responded to on a Likert scale ranging from 1 (Strongly disagree) to 5 (Strongly agree).

Social Support. We used the Multidimensional Scale of Perceived Social Support (Zimet, Dahlem, Zimet and Farley 1988). This scale comprises three 4-item subscales and assesses social support from friends: friend subscale ( $\alpha=.90$; e.g., "My friends really try to help me"); and family social support: family subscale ( $\alpha=.89$; e.g., "My family really tries to help me"). Our research team replaced the subscale 'special person' with partner social support: romantic subscale $(\alpha=.92$; e.g., "My partner really tries to help me").

\subsection{Procedure}

Specially trained members of the research team collected data in the university classroom setting. Data collection took place in the spring of 2015. All participants were informed about the purpose of the study, survey anonymity and confidentiality. Participation was voluntary. Every student present in the classroom when fieldwork was underway agreed to participate. The study received a favourable report from the Ethics Committee of Biomedical Studies from Andaloussie.

\subsection{Data Analyses}

The first step was to confirm the measurement invariance of the Flourishing Scale by sex using Confirmatory Factor Analysis (CFA). We opted for the Robust Maximum Likelihood estimation method (Satorra and Bentler 2001) by means of Lisrel 8.80 (Jöreskog and Sörbom 2006). To test for configurational invariance, the same measurement model was examined separately for each group. Metric invariance was then analysed by comparing two nested models: a baseline model and an invariance model. Because the chi-squared is highly sensitive to sample size, the following fit indexes were considered: RMSEA less than or equal to .08; CFI greater than or equal to .90; and SRMR less than .08 (Cudeck and Browne 1993; Hooper, Coughlan, and Mullen 2008; Hu and Bentler, 1999). 
De la Fuente, R., Sánchez-Queija, I., Parra, A., y Lizaso, I. (2019). Flourishing during

emerging adulthood from a gender perspective. Journal of Happiness Studies.

doi: 10.1007/s10902-019-00204-9. In press.

SPSS statistics software (version 22) was used on all other analyses. All analyses were performed separately by sex. Descriptive analyses of the study variables were carried out; ANOVAs were performed to verify the flourishing differences by level of income and markers of adulthood. Bivariate correlations were also run to analyse the relationship between male and female flourishing and the characteristics that define the emerging adulthood period, as well as the social and educational variables. Effect size was calculated for each analysis and interpreted using Cohen (1988) criteria. Fisher's Z-transformation test was used to calculate the confidence interval of the correlation coefficients in comparing the male and female subsamples (Sanchez-Bruno and Rosal 2005; Wilkinson and the APA Task Force on Statistical Inference 1999). Lastly, stepwise hierarchical regression analyses were conducted to analyse to what extent the study variables predicted flourishing in young people. Only those variables that had shown a relationship with flourishing were included as IVs in the regression analyses.

Lastly, a total-sample regression analysis was also conducted to test the significance of the moderating effect of gender on the relationships between the predictor variables and flourishing. Here a further step was incorporated into the analysis by calculating the interaction of sex with the predictor variables of flourishing. Prior to this analysis, the independent variables included in the moderation test were centered.

\section{Results}

The configurational invariance model (non-restricted model) yielded good fit indexes for both the male and female subsamples: $\mathrm{CFI}=.96$ and .95 , respectively; RMSEA $=.09$ for both subsamples; and SRMR= .046 and .047 , respectively. These data reveal a good fit of the unifactorial flourishing model for males as well as females. Metric invariance was also examined to ensure that the psychological meaning of the flourishing construct did not vary across groups (Xu and Tracey 2017). The fit indexes of the baseline model were $\mathrm{CFI}=.94$, $\mathrm{RMSEA}=.10$, and $\mathrm{SRMR}=.05$, whereas the fit indexes of the invariance model's constraints were $\mathrm{CFI}=.93$, RMSEA $=.10$, and $\mathrm{SRMR}=.097$. Reporting $\triangle \mathrm{CFI}=.01$, we can consider the models invariant (Meade, Johnson and Braddy 2008), and the psychological meaning of flourishing as similar across sexes.

The descriptive analyses by sex indicated no differences between males and females for level of income $\left(X^{2}=5.6, p=.06\right)$ and living with who $\left(X^{2}=.63, p=.43\right)$. Females reported more employment $\left(X^{2}=7.77, p=.005\right)$ and fewer dating partners $\left(X^{2}=27.19, p<.001\right)$ than expected by chance, higher scores in the IDEA dimensions, better grades, increased prioritising of studies, and more social support than their male counterparts (see Table 2). Furthermore, the data showed that flourishing was significantly higher in females $(M=47.11, S D=5.08)$ than in males $(M=45.98 ; S D=6.13)$. Due to the unequal male/female demographic variances $(F=22.12, p<.001)$, a corrected t-test $(t(113.92)=-3.73$, $p<.001)$ was used to check for statistical significance. Participant age did not correlate significantly with flourishing $(r=.04, p=.17)$.

As shown in Table 1, the ANOVA revealed significant differences in flourishing by level of income only in the case of females, but yielded a negligible effect size. The marker of adulthood variable having $a$ job was significant for flourishing in females only, but yielded a negligible effect size. In the case of 
De la Fuente, R., Sánchez-Queija, I., Parra, A., y Lizaso, I. (2019). Flourishing during emerging adulthood from a gender perspective. Journal of Happiness Studies.

doi: 10.1007/s10902-019-00204-9. In press.

being in a relationship, it was only a significant variable for male flourishing, yielding a small effect size.

Living or not in the family home showed no relationship to flourishing in either sex.

Table 1 Descriptive analyses and ANOVAs of male and female flourishing levels by study variables

\begin{tabular}{|c|c|c|c|c|c|c|c|c|c|c|c|c|}
\hline \multicolumn{4}{|c|}{ Level of income } & \multicolumn{3}{|c|}{ Employment } & \multicolumn{3}{|c|}{ Partner } & \multicolumn{3}{|c|}{ Living with who } \\
\hline Low & $\begin{array}{c}\text { Middl } \\
\mathrm{e}\end{array}$ & High & $\begin{array}{c}F \\
\left(\eta^{2}\right)\end{array}$ & Yes & No & $\begin{array}{c}t \\
\left(\eta^{2}\right)\end{array}$ & Yes & No & $\begin{array}{c}t \\
\left(\eta^{2}\right)\end{array}$ & $\begin{array}{c}\text { Parent } \\
\text { S }\end{array}$ & $\begin{array}{c}\text { Other } \\
\mathrm{s}\end{array}$ & $\begin{array}{c}t \\
\left(\eta^{2}\right)\end{array}$ \\
\hline $\begin{array}{l}\text { Mean } \\
\text { (SD) }\end{array}$ & $\begin{array}{l}\text { Mean } \\
\text { (SD) }\end{array}$ & $\begin{array}{l}\text { Mean } \\
\text { (SD) }\end{array}$ & & $\begin{array}{l}\text { Mean } \\
\text { (SD) }\end{array}$ & $\begin{array}{l}\text { Mean } \\
\text { (SD) }\end{array}$ & & $\begin{array}{l}\text { Mean } \\
\text { (SD) }\end{array}$ & $\begin{array}{l}\text { Mean } \\
\text { (SD) }\end{array}$ & & $\begin{array}{l}\text { Mean } \\
\text { (SD) }\end{array}$ & $\begin{array}{l}\text { Mean } \\
\text { (SD) }\end{array}$ & \\
\hline $\begin{array}{l}\text { Max- } \\
\text { Min }\end{array}$ & $\begin{array}{l}\text { Max- } \\
\text { Min }\end{array}$ & $\begin{array}{l}\text { Max- } \\
\text { Min }\end{array}$ & & $\begin{array}{l}\text { Max- } \\
\text { Min }\end{array}$ & $\begin{array}{l}\text { Max- } \\
\text { Min }\end{array}$ & & $\begin{array}{l}\text { Max- } \\
\text { Min }\end{array}$ & $\begin{array}{l}\text { Max- } \\
\text { Min }\end{array}$ & & $\begin{array}{l}\text { Max- } \\
\text { Min }\end{array}$ & $\begin{array}{l}\text { Max- } \\
\text { Min }\end{array}$ & \\
\hline
\end{tabular}

\begin{tabular}{|c|c|c|c|c|c|c|c|c|c|c|c|c|c|}
\hline \multicolumn{14}{|c|}{ Flourishing } \\
\hline Female & 46.81 & 47.00 & 48.18 & $3.01 *$ & 47.81 & 46.95 & - & 47.41 & 46.77 & 1.85 & 47.27 & 46.83 & 1.26 \\
\hline $\mathrm{s}$ & $(4.80$ & (5.12) & $(5.12$ & $(.007$ & $(4.01$ & $(5.30$ & $2.04 *$ & $(4.80$ & $(5.46$ & $(.004)$ & (5.04) & $(5.14)$ & $(.002$ \\
\hline
\end{tabular}

Table 2 shows the bivariate correlations between flourishing and the characteristics of emerging adulthood, the educational variables, and the social support variables. Flourishing correlated positively and significantly with two emerging adulthood characteristics in both males and females: self-focus and a time of experimentation/possibilities. These correlations were significantly greater in males than in females (Fisher's $\mathrm{Z}=2.13, p=.02$ and Fisher's $\mathrm{Z}=2.88, p<.001$, respectively).

Table 2 Descriptive analyses and Pearson correlations between flourishing and the study variables

\begin{tabular}{|c|c|c|c|c|c|}
\hline \multirow[b]{2}{*}{ Variables } & \multicolumn{2}{|c|}{ Males } & \multicolumn{2}{|c|}{ Females } & \multirow[b]{2}{*}{$\begin{array}{c}\text { Sex differences } \\
t\end{array}$} \\
\hline & $\begin{array}{c}\text { Mean (SD) } \\
\text { Max-Min }\end{array}$ & $\begin{array}{c}\text { Flourishing } \\
\text { rxy }\end{array}$ & $\begin{array}{c}\text { Mean (SD) } \\
\text { Max-Min }\end{array}$ & $\begin{array}{c}\text { Flourishing } \\
r x y\end{array}$ & \\
\hline \multicolumn{6}{|l|}{ IDEA } \\
\hline Identity exploration & $\begin{array}{c}3.08(.51) \\
4-1.14\end{array}$ & .056 & $\begin{array}{c}3.18(.52) \\
4-1.29\end{array}$ & .024 & $-3.41 * * *$ \\
\hline Experimentation/Possibilities & $\begin{array}{c}3.39(.52) \\
4.2-1\end{array}$ & $.23 * *$ & $\begin{array}{c}3.47(.57) \\
12-1.20\end{array}$ & $.12 * *$ & $-2.80 * *$ \\
\hline Self-focus & $\begin{array}{c}3.25(.46) \\
4-1\end{array}$ & -.036 & $\begin{array}{c}3.33(.45) \\
4-1.5\end{array}$ & -.042 & $-3.18 * *$ \\
\hline Feeling in-between & $\begin{array}{c}2.90(.66) \\
4-1\end{array}$ & $.36^{* *}$ & $\begin{array}{c}3.00(.66) \\
4-1\end{array}$ & $.22 * *$ & $-2.91 * *$ \\
\hline \multicolumn{6}{|l|}{ Educational variables } \\
\hline Achieving good grades & $\begin{array}{c}3.67(.95) \\
5-1\end{array}$ & $.39 * *$ & $\begin{array}{c}3.98(.84) \\
6-1\end{array}$ & $.26^{* *}$ & $-6.47 * * *$ \\
\hline Prioritising studies & $\begin{array}{c}4.04(.83) \\
5-1\end{array}$ & $.25^{*}$ & $\begin{array}{c}4.18(.86) \\
6-1\end{array}$ & $.22 * *$ & $-3.22 * * *$ \\
\hline \multicolumn{6}{|l|}{ Social support } \\
\hline Friends & $\begin{array}{c}5.90(1.13) \\
7-1\end{array}$ & $.38 * *$ & $\begin{array}{c}6.14(1.15) \\
7-1\end{array}$ & $.27 * *$ & $-4.0 * * *$ \\
\hline Family & $\begin{array}{c}6.06(1.26) \\
7-1\end{array}$ & $.42 * *$ & $\begin{array}{c}6.21(1.15) \\
7-1\end{array}$ & $.24 * *$ & $-2.38 *$ \\
\hline Partner & $\begin{array}{c}6.40(1.09) \\
7-1\end{array}$ & $.43 * *$ & $\begin{array}{c}6.56(.78) \\
7-1\end{array}$ & $.15^{* *}$ & $-2.4^{*}$ \\
\hline
\end{tabular}

Significant correlations were also observed between flourishing and achieving good grades and prioritising studies in males and females. In this case, the correlations were similar across sexes (Fisher's $\mathrm{Z}=.71, p=.48$; Fisher's $\mathrm{Z}=.68 ; p=.50)$. 
De la Fuente, R., Sánchez-Queija, I., Parra, A., y Lizaso, I. (2019). Flourishing during emerging adulthood from a gender perspective. Journal of Happiness Studies.

doi: 10.1007/s10902-019-00204-9. In press.

The data for social support showed positive and significant correlations between social support (friends, family and partner) and flourishing level. These correlations were significantly higher in males than in females (Fisher's $Z=2.33, p=.009$; Fisher's $Z=3.83 ; p<.001$ and Fisher's $Z=4.14 ; p<.001$ respectively).

A stepwise hierarchical regression analysis was performed to identify which study variables allow us to better predict male and female flourishing. The variables for both sexes were introduced in the same order, selecting only those variables that had shown significant relationships with flourishing in at least one of the two subsamples: male and female.

First, we introduced the sociodemographic variable that had shown to be related (Step 1). This enabled us to control for the role of family income in flourishing. We then included those variables related to the developmental stage. This was done in two steps: taking into account the variables considered developmental task variables (Step 2) and whether the young people believe that the developmental stage meets its defining characteristics (Step 3). Thus, we get a picture of whether the young people's actions that society deems correct affect their flourishing. Because the study participants are university students, the aspects related to their studies make up Step 4. Lastly, we included relational variables as Step 5; specifically, those associated with their relational support network: friends, family and partner, core variables in personal well-being.

Table 3. Linear regression analysis predicting male, female and total sample flourishing

\begin{tabular}{|c|c|c|c|c|c|c|}
\hline \multirow[b]{2}{*}{ Predictors } & \multicolumn{2}{|c|}{ Males } & \multicolumn{2}{|c|}{ Females } & \multicolumn{2}{|c|}{ Total } \\
\hline & $\beta$ & $\Delta R^{2}$ & $\beta$ & $\Delta R^{2}$ & $\beta$ & $\Delta R^{2}$ \\
\hline Step 0 & & -- & & --- & & .007 \\
\hline Sex & -- & & -- & & $.08 *$ & \\
\hline Step 1 & & .01 & & & & .005 \\
\hline Sex & -- & & -- & & .08 & \\
\hline Level of income & .08 & & .06 & & .07 & \\
\hline Step 2 & & .05 & & .00 & & .018 \\
\hline Sex & -- & & -- & & $.07 *$ & \\
\hline Level of income & .09 & & .06 & & .07 & \\
\hline Having a job & .04 & & .01 & & .02 & \\
\hline Being in a relationship & $.21 * *$ & & .05 & & $.131 * * *$ & \\
\hline Step 3 & & .17 & & .04 & & .082 \\
\hline Sex & -- & & -- & & .05 & \\
\hline Level of income & .06 & & .05 & & .06 & \\
\hline Having a job & .03 & & -.00 & & .01 & \\
\hline Being in a relationship & $.17 * *$ & & .05 & & $.13 * * *$ & \\
\hline Experimentation/Possibilities & -.04 & & .09 & & .03 & \\
\hline Self-focus & $.43 * * *$ & & $.14 *$ & & $.27 * * *$ & \\
\hline Step 4 & & .07 & & .06 & & .068 \\
\hline Sex & -- & & -- & & .02 & \\
\hline Level of income & .06 & & .05 & & .05 & \\
\hline Having a job & .02 & & .03 & & .03 & \\
\hline Being in a relationship & $.16^{* *}$ & & .05 & & $.12 * * *$ & \\
\hline Experimentation/Possibilities & -.05 & & .07 & & .01 & \\
\hline Self-focus & $.39 * * *$ & & $.11 *$ & & $.24 * * *$ & \\
\hline Achieving good grades & $.24 * * *$ & & $.18 * * *$ & & $.21 * * *$ & \\
\hline Prioritising studies & .07 & & $.13 * *$ & & $.11 * *$ & \\
\hline Step 5 & & .17 & & .05 & & .102 \\
\hline Sex & -- & & -- & & -.15 & \\
\hline
\end{tabular}


De la Fuente, R., Sánchez-Queija, I., Parra, A., y Lizaso, I. (2019). Flourishing during emerging adulthood from a gender perspective. Journal of Happiness Studies. doi: 10.1007/s10902-019-00204-9. In press.

Level of income

Having a job

Being in a relationship

Experimentation/Possibilities

Self-focus

Achieving good grades

Prioritising studies

Support from friends

Support from family

Support from partner

Step 6: interaction terms ${ }^{1}$

$\begin{array}{ccc}.06 & .03 & .03 \\ .05 & .03 & .03 \\ .02 & .03 & .04 \\ -.07 & .06 & .00 \\ .29 * * * & .09 & .19 * * * \\ .22 * * * & .17 * * * & .19 * * * \\ .04 & .12 * * & .09 * * \\ .19 * * * & .16 * * * & .16 * * * \\ .14 * * & .09 & .14 * * * \\ .34 * * * & .07 & .18 * * * \\ & & \end{array}$

.099

$-.21 * * *$

$-.06$

.05

$-.08$

$-.06$

$-.14 * *$

.034

.16

Note: $* \mathrm{p} \leq .05 ; * * \mathrm{p} \leq .01 ; * * * \mathrm{p} \leq .001 ; 1$. For ease of reading, Step 6 of the table only features the interaction data, although the effects of each variable were previously included in the regression equation.

Table 3 summarises some salient results. First, the model described in Step 5 explains 46\% of the variance in males as opposed to $16 \%$ in females. Second, the introduction of the variables self-focused $\left(\Delta \mathrm{R}^{2}=.17\right)$ and perceived social support from family, friends and partner $\left(\Delta \mathrm{R}^{2}=.17\right)$ plays an important role in male flourishing. Lastly, the variables that make males and females flourish are not always the same. In the case of males, Step 5 shows the variables associated with flourishing in order of importance to be: support from one's partner, self-focus, achieving good grades at university, social support from friends, and social support from family. In the case of females, they coincide with their male peers in the importance of social support from friends and achieving good grades at university. However, the third predictor variable of flourishing in females was considering their studies a priority in life. For them, social support from the family and partner and being self-focused was not a predictor of flourishing, much like prioritising studies was not a predictor for their male counterparts.

Lastly, the moderation test (Step 6) confirmed that the relationships between the self-focused variable and partner social support with flourishing are significantly moderated by sex. Furthermore, and as also confirmed in Step 5 of the regression analysis, these variables are important in male flourishing but not so in female flourishing.

\section{Discussion}

The aim of this research paper was to analyse the variables associated with flourishing in a sample of Spanish emerging adults from a gender perspective. The metric invariance of the Flourishing Scale showed the psychological meaning of this measure to be similar in males and females, thus rendering the comparison of both groups based on this measure as valid. This comparison revealed that female flourishing is greater than male flourishing. This result is contrary to those found by Keyes and 
De la Fuente, R., Sánchez-Queija, I., Parra, A., y Lizaso, I. (2019). Flourishing during

emerging adulthood from a gender perspective. Journal of Happiness Studies.

doi: 10.1007/s10902-019-00204-9. In press.

colleagues, who reported greater flourishing in males (Keyes 2007; Keyes and Simoes 2012; Keyes et al. 2002), yet similar to earlier studies, including those of Ando (2014) and Schotanus-Dijkstra et al. (2016) on flourishing and subjective well-being, in which we can also appreciate these gender differences in favour of females (Blanchflower and Oswald 2004; Graham and Chattopadhyay 2012; Stevenson and Wolfers 2009; Zweig 2015). Although researchers have been unable to clarify the reason behind these differences (Batz and Tay 2018), Arrosa argued that a type of "female optimism" exists (Arrosa and Gandelman 2016, p. 733), which makes women value their characteristics and life situations in a more positive light than men. This was after identifying how women reported enhanced well-being despite experiencing poorer objective living conditions in three large international samples.

Perhaps the most salient result to emerge from our study is that the analysed variables explain $46 \%$ of the flourishing variance in males and only $16 \%$ in females. Specifically, males flourish less during emerging adulthood, although we are able to identify a significant number of predictors for their flourishing, whereas females flourish more but the reasons are less clear. That said, this flourishing was less explained by the sociodemographic variables than by the substantive variables in this study across both sexes and in accordance with previous studies on predictors of well-being (Demir and Weitekamp 2007; Lamers, Westerhof, Kovács and Bohlmeijer 2012; Waterman et al. 2010) and flourishing (Schotanus-Dijkstra et al. 2016). In fact, the level of family income in this study showed no relationship to flourishing. This means that our research provides revelant information about which factors can be promoted to strengthen flourishing, at least in males.

The regression equation showed the predictors of flourishing in males to be-in order of prioritysupport from one's partner, being self-focused, achieving good grades at university, social support from friends, and social support from family. Although the means comparisons revealed that males in current relationships flourish more than single males, the regression equation showed that social support given by the respective partner is what facilitates flourishing in males more so than being in a relationship or not. However, this was not a relevant variable for females, a finding which was confirmed in the interaction analysis. The partner's role in flourishing could well be related to the protective function of dating relationships among emerging adults when faced with risk behaviours and those with negative consequences for health (Braithwaite et al. 2010). In Braithwaite's study, this relationship was similar for both males and females. Although we have no definitive explanation as to why, in our study, this relationship emerged in males only, perhaps the 'having a supportive partner-flourishing' dyad in males results from the fact that they view sex as a more important factor for achieving happiness than their female peers during emerging adulthood (Crossley and Langdridge 2005), and being in a supportive relationship facilitates this sexual activity.

Social support has also proved relevant for flourishing. Family social support holds more importance for males than for females. This result coincides with O'Connor et al.'s (2011) study. As argued by the aforementioned authors, one possible explanation would be that perceived family social support is more stable for females during adolescence and emerging adulthood, whereas for males this perception of support shifts, in that it decreases during adolescence and stabilises later on (Helsen, Vollebergh and 
De la Fuente, R., Sánchez-Queija, I., Parra, A., y Lizaso, I. (2019). Flourishing during

emerging adulthood from a gender perspective. Journal of Happiness Studies.

doi: 10.1007/s10902-019-00204-9. In press.

Meeus 2000). Thus, changes in the relationship with their parents over these years would be particularly relevant to male well-being. Social support from friends was also a relevant predictor of flourishing across both genders. Previous research has shown the importance of peer relations in flourishing (Ando 2014; Huppert and So 2013; O’Connor et al. 2011; Schulenberg, Bryant and O'Malley 2004).

Flourishing in males is also predicted by being self-focused, a predictor that does not appear in the regression equation for females. The difference in self-focus between both sexes is seen in the interaction effect of the variable with the total sample. This variable is defined by considering this stage a time of personal freedom, responsibility for oneself, optimism, independence, self-sufficiency, and trying out new things. No other stage of life sees people focus so much on themselves quite like emerging adulthood (Arnett 2015). Yet this "egocentrism" is normal and even healthy, as its positive relationship with flourishing shows. The question that emerges is: why does this psychosocial moratorium, this period of freedom, not lead to flourishing for females? The answer is not that males can be self-focused and females cannot, as both sexes acknowledge this period as a time of self-focus. In our view, there may be two possible answers. One has to do with the construction of the female identity, most closely linked to the ethics of care (Chodorow 1989) and interdependence (i.e., more relationships) (Cross and Madson 1997; Padilla-Walker et al. 2008), which would mean that being self-focused becomes less important to females' flourishing. The other possibility comes from prior history. Females would have tested their maturity, decision-making skills, and taking responsibility for themselves during adolescence (Schultz, Selman and LaRusso 2003), meaning that being self-focused would hold no importance to their flourishing during emerging adulthood.

Coinciding with earlier studies (Datu 2018; Paciello, Ghezzi, Tramontano, Barbaranelli and Fida 2016; Phan 2016; Seligman et al. 2009), achieving good grades - that is, their perceived capabilities for managing learning-related behaviour-is particularly relevant to both male and female flourishing. In other words, flourishing in young people is related to seeing how the challenges that are taking shape - in this case, getting good academic grades - are being achieved. Besides confirming the findings of previous studies, this result highlights the importance of also including academic advice and support initiatives in university degree programmes.

In the explanatory model of female flourishing, a variable is introduced that does not figure in the male model: "My studies are a priority". However, if we look at the correlations table, this variable holds almost equal importance to both males and females. We would argue that it is neither more nor less important to both sexes; rather, it is part of the model among girls given the few variables that comprise the female model. In the male model, the strength of other relationships prevails over this one. In any case, for both sexes to view this core activity as a priority fits with the eudaemonic perspective of flourishing, thus giving meaning and purpose to the lives of emerging adults (Agenor, Conner and Aroian 2017).

Lastly, and contrary to the working hypotheses, the resolution of developmental tasks inherent in emerging adulthood was not related to well-being. The effect size tests have also shown that having a job 
De la Fuente, R., Sánchez-Queija, I., Parra, A., y Lizaso, I. (2019). Flourishing during

emerging adulthood from a gender perspective. Journal of Happiness Studies.

doi: 10.1007/s10902-019-00204-9. In press.

and living independently were not associated with flourishing. Both findings could be explained by the current Spanish context: a reality in which over $40 \%$ of young people are unemployed and the majority live at home until almost 30 years of age (Eurostat 2017c). Coupled with the fact that our sample's average age stood at around 20, it is likely that having a job or living away from home would not yet be developmental tasks for our study participants.

To conclude and in line with earlier research (Crosley 2005), we identified a central structure encompassing common factors when explaining flourishing in males and females and which complement other gender-specific factors. If we look at the comparison of means and correlation analyses, we practically see the same variables relating to male and female flourishing, although yielding different strengths. As such, it was the regression analysis that showed more differences in the predictors of flourishing for males and females. Furthermore, we continue to observe similarities in this analysis: the importance of succeeding in their main endeavour - their studies - and the importance of peer support. But there are also differences: the importance of prioritising studies for female flourishing and the importance of self-focus and support from family and partner for male flourishing. Of all these variables, only self-focus and support from partner show an interaction effect with sex in the regression equation. These are the two variables that cause the most differences in flourishing depending on sex. In this way, our results support the need to generate lines of intervention that contribute to the flourishing during emerging adulthood and are sensitive to gender differences, and are also capable of promoting well-being in both, taking into account their similarities but also their differences.

\subsection{Limitations, strengths and future research directions}

The study findings need to be considered by taking into account three limitations. First, the current research was based on self-report data, which may have been influenced by social desirability bias. That said, these types of instruments are widely used and have reported a high degree of validity (Lucas et al., 1996; Sandvik, Diener and Seidlitz 1993). Second, because our sample comprises university students exclusively, it is not possible to generalise the results to other populations. The third and final limitation has to do with the average age of the sample $(M=19.95)$, which means we need to exercise a degree of caution when generalising the results to the whole emerging adulthood stage of life.

Despite these limitations, this study is the first to verify the metric invariance of the Flourishing Scale in males and females, which represents a step forward in flourishing operationalisation and, in turn, its conceptualisation. Moreover, our study represents an important one given that there are very few studies conducted in Spain that seek to understand flourishing in emerging adulthood, and even fewer from a gender perspective. That said, the conclusions drawn in this discussion are somewhat speculative, particularly regarding sex-related differences, as we have been unable to find alternative explanations in the scientific literature.

Taking into account the weak prediction of flourishing in the female model, an interesting and necessary future line of research would be to include new variables that could shed light on female well- 
De la Fuente, R., Sánchez-Queija, I., Parra, A., y Lizaso, I. (2019). Flourishing during emerging adulthood from a gender perspective. Journal of Happiness Studies.

doi: 10.1007/s10902-019-00204-9. In press.

being. Only by knowing what makes females flourish can help guide interventions to promote their flourishing. It would also be interesting to approach this from a longitudinal perspective to determine not only the stability of flourishing during these years of change, but also the directionality of the findings. In other words, does success in one's studies help one to flourish or does flourishing itself encourage academic success?

The present study has contributed towards understanding emerging adulthood in a non-Englishspeaking context, a period conditioned by the sociocultural characteristics in which young people develop (Arnett 2003). This knowledge should enable the development of evidence-based intervention programmes aimed at improving young people's well-being, thus facilitating a smooth transition to adulthood.

\section{References}

Agenor, C., Conner, N., \& Aroian, K. (2017). Flourishing: An Evolutionary Concept Analysis. Issues in Mental Health Nursing, 38(11), 915-923. https://doi.org/10.1080/01612840.2017.1355945

Alberdi, I., Escario, P., \& Matas, N. (2000). Young Women in Spain. Barcelona: Fundación la Caixa.

Ando, S. (2014). Flourishing among Japanese Immigrants: A Positive Approach to Understanding Psychosocial Adaptation. Journal of Human Behavior in the Social Environment, 24(3), 301-315. https://doi.org/10.1080/10911359.2013.831008

Argyle, M. (2001). The psychology of happiness (2nd ed.). New York: Routledge.

Arnett, J. J. (2000). Emerging adulthood: A theory of development from the late teens through the twenties. American Psychologist, 55(5), 469-480. https://doi.org/10.1037/0003-066X.55.5.469

Arnett, J. J. (2003). Conceptions of the Transition to Adulthood Among Emerging Adults in American Ethnic Groups. In J. J. Arnett \& N. L. Galambos (Eds.), New Directions for Child and Adolescent Development: Exploring cultural conceptions of the transition to adulthood (pp. 63-75). https://doi.org/10.1002/cd.75

Arnett, J. J. (2004). Young adulthood: The winding road from the late teens through the twenties. New York: Oxford University Press.

Arnett, J. J. (2007a). Emerging Adulthood : What Is It , and What Is It Good For? Child Development Perspectives, 1(2), 68-73. https://doi.org/10.1111/j.1750-8606.2007.00016.x

Arnett, J. J. (2007b). Suffering, selfish, slackers? Myths and reality about emerging adults. Journal of Youth and Adolescence, 36(1), 23-29. https://doi.org/10.1007/s10964-006-9157-z

Arnett, J. J. (2015). Emerging adulthood: The winding road from the late teems through the twenties (2nd ed.). New York: Oxford University Press.

Arrosa, M. L., \& Gandelman, N. (2016). Happiness decomposition: Female optimism. Journal of Happiness Studies, 17(2), 731-756. https://doi.org/DOI 10.1007/s10902-015-9618-8 
De la Fuente, R., Sánchez-Queija, I., Parra, A., y Lizaso, I. (2019). Flourishing during emerging adulthood from a gender perspective. Journal of Happiness Studies. doi: 10.1007/s10902-019-00204-9. In press.

Aseltine, R. H., \& Gore, S. (1993). Mental Health and Social Adaptation Following the Transition From High School. Journal of Research on Adolescence, 3(3), 247-270. https://doi.org/10.1111/15327795.ep11301466

Bachman, J. G., Johnston, L. D., O’Malley, P. M., \& Schulenberg, J. (1996). Transitions in drug use during late adolescence and young adulthood. In J. A. Graber, J. Brooks-Gunn, \& A. C. Petersen (Eds.), Transitions through adolescence: Interpersonal domains and context. (pp. 111-140). Mahwah, N J: Lawrence Erlbaum.

Batz, C., \& Tay, L. (2018). Gender Differences in Subjective Well-Being. In L. T. E. Diener, S. Oishi (Ed.), Handbook of well-bein (pp. 1-15). Salt Lake City, UT: DEF Publishers. https://doi.org/nobascholar.com

Blanchflower, D. G., \& Oswald, A. J. (2004). Well-being over time in Britain and the USA. Journal of Public Economics, 88(7-8), 1359-1386. https://doi.org/10.1016/S0047-2727(02)00168-8

Braithwaite, S. R., Delevi, R., \& Fincham, F. D. (2010). Romantic relationships and the physical and mental health of college students. Personal Relationships, 17(1), 1-12. https://doi.org/10.1111/j.1475-6811.2010.01248.x

Caunt, B. S., Franklin, J., Brodaty, N. E., \& Brodaty, H. (2012). Exploring the Causes of Subjective WellBeing: A Content Analysis of Peoples' Recipes for Long-Term Happiness. Journal of Happiness Studies, 14(2), 475-499. https://doi.org/10.1007/s10902-012-9339-1

Chodorow, N. (1989). Feminism and psychoanalytic theory. New Haven, CT: Yale University Press.

Cohen, J. (1988). Statistical power analysis for the behavioral sciences. 2nd. Hillsdale, NJ: erlbaum.

Cross, S. E., \& Madson, L. (1997). Models of the self: Self-construals and gender. Psychological Bulletin, 122(1), 5-37. https://doi.org/10.1037/0033-2909.122.1.5

Crossley, A., \& Langdridge, D. (2005). Perceived sources of happiness: A network analysis. Journal of Happiness Studies, 6(2), 107-135. https://doi.org/10.1007/s10902-005-1755-z

Cudeck, R., y Brown, M. (1983). Cross-validation in covariance structures. Multivariate Research, 18, 147-167.

Datu, J. A. D. (2018). Flourishing is Associated with Higher Academic Achievement and Engagement in Filipino Undergraduate and High School Students. Journal of Happiness Studies, 19 (1), 27-39. https://doi.org/10.1007/s10902-016-9805-2

De la Fuente, R., Parra, A., \& Sánchez-Queija, I. (2017). Psychometric Properties of the Flourishing Scale and Measurement Invariance Between Two Samples of Spanish University Students. Evaluation \& the Health Professions, 40(4), 409-424. https://doi.org/10.1177/0163278717703446

Delgado Gallego, I., Oliva, A., \& Sánchez-Queija, I. (2011). Apego a los iguales durante la adolescencia y la adultez emergente [Peers attachment during adolescence and emerging adulthood ${ }^{1}$. Anales de Psicologia, 27(1), 155-163.

Demir, M., \& Weitekamp, L. A. (2007). I am so happy 'cause today I found my friend: Friendship and personality as predictors of happiness. Journal of Happiness Studies, 8(2), 181-211. https://doi.org/10.1007/s10902-006-9012-7

DeNeve, K. M., \& Cooper, H. (1998). The happy personality: A meta analysis of 137 personality traits of subjective well-being. Psychological Bulletin, 124(2), 197-229. https://doi.org/0033-2909/98/S3.00 
De la Fuente, R., Sánchez-Queija, I., Parra, A., y Lizaso, I. (2019). Flourishing during emerging adulthood from a gender perspective. Journal of Happiness Studies. doi: 10.1007/s10902-019-00204-9. In press.

Diener, E., Lucas, R. E., \& Oishi, S. (2018). Advances and Open Questions in the Science of Subjective Well-Being. Collabra Psychology, 4(1), 1-78. https://doi.org/10.1525/collabra.

Diener, E., \& Ryan, R. M. (2009). Subjective well-being : a general overview. South African Journal of Pscyhology, 39(4), 391-406.

Diener, E., \& Seligman, M. E. P. (2002). Very Happy People. Psychological Science, 13(December), 8184. http://dx.doi.org/10.1111/j.1360-0443.2005.01292.x

Diener, E., \& Seligman, M. E. P. (2004). Beyond Money Toward an Economy of Well-Being. Psychological Science in the Public Interest, 5(1), 1-31. https:// doi: 10.1111/j.09637214.2004.00501001.x

Diener, E., Suh, E. M., Lucas, R. E., \& Smith, H. L. (1999). Subjective well-being: Three decades of progress. Psychological Bulletin, 125(2), 276-302. https://doi.org/10.1037/0033-2909.125.2.276

Diener, E., Wirtz, D., Tov, W., Kim-Prieto, C., Choi, D. W., Oishi, S., \& Biswas-Diener, R. (2010). New well-being measures: Short scales to assess flourishing and positive and negative feelings. Social Indicators Research, 97(2), 143-156. https://doi.org/10.1007/s11205-009-9493-y

Dogan, T., Totan, T., \& Sapmaz, F. (2013). The Role Of Self-esteem, Psychological Well-being, Emotional Self-efficacy, And Affect Balance On Happiness: A Path Model. European Scientific Journal, 9(20), 31-42.

Dolan, P., Peasgood, T., \& White, M. (2008). Do we really know what makes us happy? A review of the economic literature on the factors associated with subjective well-being. Journal of Economic Psychology, 29, 94-122. https://doi.org/10.1016/j.joep.2007.09.001

Dubas, J. S., \& Petersen, A. C. (1996). Geographical distance from parents and adjustment during adolescence and young adulthood. New Directions for Child and Adolescent Development, 71, 319. https://doi.org/10.1002/cd.23219967103

Eurostat. (2017a). Employment Statistics. Retrieved November 1, 2017, from http://ec.europa.eu/eurostat/statistics-explained/index.php/Employment_statistics/es

Eurostat. (2017b). Eurostat Regional Yearbook 2017 edition. Luxembourg: Publications Office of the European Union, 2017. https://doi.org/10.2785/257716

Eurostat. (2017c). When are they ready to leave the nest? Retrieved November 1, 2017, from http://ec.europa.eu/eurostat/web/products-eurostat-news/-/EDN-201705031 ? inheritRedirect=true\&redirect $=\% 2$ Feurostat $\% 2 \mathrm{~F}$

Galambos, N. L., Barker, E. T., \& Krahn, H. J. (2006). Depression, self-esteem, and anger in emerging adulthood: seven-year trajectories. Developmental Psychology, 42(2), 350-365. https://doi.org/10.1037/0012-1649.42.2.350

Gestsdottir, S., Arnarsson, A., Magnusson, K., Arngrimsson, S. A., Sveinsson, T., \& Johannsson, E. (2015). Gender differences in development of mental well-being from adolescence to young adulthood : An eight-year follow-up study. Scandinavian Journal of Public Health, 43(3), 269-275. https://doi.org/10.1177/1403494815569864

Graham, C., \& Chattopadhyay, S. (2012). Human Capital and Economic Opportunity: Gender and WellBeing around the World: Some Insights from the Economics of Happiness. Working Paper Series $N^{o}$. 2012-010. Retrieved December 15, 2017, from 
De la Fuente, R., Sánchez-Queija, I., Parra, A., y Lizaso, I. (2019). Flourishing during emerging adulthood from a gender perspective. Journal of Happiness Studies. doi: 10.1007/s10902-019-00204-9. In press.

http://www.brookings.edu/research/papers/2012/08/gender-well-being-graham

Havighurst, R. J. (1952). Developmental tasks and education. New York: McKay.

Heckhausen, J. (1999). Developmental regulation in adulthood: Age-normative and sociostructural constraints as adaptive challenges. New York: Cambridge University Press.

Helsen, M., Vollebergh, W., \& Meeus, W. (2000). Social Support from Parents and Friends and Emotional Problems in Adolescence. Journal of Youth and Adolescence, 29(3), 319-335. https://doi.org/10.1023/A:1005147708827.

Hone, L. C., Jarden, A., Schofield, G., \& Duncan, S. (2014). Measuring flourishing: The impact of operational definitions on the prevalence of high levels of wellbeing. International Journal of Wellbeing, 4(1), 62-90. https://doi.org/10.5502/ijw.v4i1.4

Howard Sharp, K. M., Schwartz, L. E., Barnes, S. E., Jamison, L. E., Miller-Graff, L. E., \& Howell, K. H. (2017). Differential Influence of Social Support in Emerging Adulthood Across Sources of Support and Profiles of Interpersonal and Non-Interpersonal Potentially Traumatic Experiences. Journal of Aggression, Maltreatment \& Trauma, 26(7), 736-755.

Hooper, D., Coughlan, J., \& Mullen (2008). Structural equation modelling: guidelines for determining model fit. The Electronic Journal of Business Research Methods, 6, 53-60.

Hu, L.T., \& Bentler, P. M. (1999). Cutoff criteria for fit indexes in covariance structure analysis: Conventional criteria versus new alternatives. Structural Equation Modeling, 6, 1-55. doi:10.1080/10705519909540118

Huppert, F. A. (2009). Psychological well-being: Evidence regarding its causes and consequences. Applied Psychology: Health and Well-Being, 1(2), 137-164. https://doi.org/10.1111/j.17580854.2009.01008.x

Huppert, F. A., \& So, T. T. C. (2009). What percentage of people in Europe are flourishing and what characterises them. IX ISQOLS Conference, 1-7. Retrieved Mars 25, 2018, from http://www.isqols2009.istitutodeglinnocenti.it/Content_en/Huppert.pdf

Huppert, F. A., \& So, T. T. C. (2013). Flourishing Across Europe: Application of a New Conceptual Framework for Defining Well-Being. Social Indicators Research, 110(3), 837-861. https://doi.org/10.1007/s11205-011-9966-7

INE. (2018). Economically Active Population Survey. Retrieved November 1, 2017, from http://www.ine.es/dyngs/INEbase/es/operacion.htm?c=Estadistica_C\&cid=1254736176918\&menu =ultiDatos\&idp=1254735976595

INJUVE. (2016). Spanish Youth Report 2016. Minstry of Health, Social Services and Equality. Madrid. Retrieved November 1, 2017 from http://www.injuve.es/observatorio/demografia-e-informaciongeneral/informe-juventud-en-espana-2016

Jöreskog, K. G., \& Sörbom, D. (2006). LISREL (version 8.80)[computer software]. Lincolnwood, IL: Scientific Software International.

Keyes, C. L. M. (2002). The mental health continuum: from languishing to flourishing in life. Journal of Health and Social Behavior, 43(2), 207-222. https://doi.org/10.2307/3090197

Keyes, C. L. M. (2007). Promoting and protecting mental health as flourishing: a complementary strategy for improving national mental health. The American Psychologist, 62(2), 95-108. 
De la Fuente, R., Sánchez-Queija, I., Parra, A., y Lizaso, I. (2019). Flourishing during emerging adulthood from a gender perspective. Journal of Happiness Studies.

doi: 10.1007/s10902-019-00204-9. In press.

https://doi.org/10.1037/0003-066X.62.2.95

Keyes, C. L. M., Shmotkin, D., \& Ryff, C. D. (2002). Optimizing well-being: The empirical encounter of two traditions. Journal of Personality and Social Psychology, 82(6), 1007-1022. https://doi.org/10.1037//0022-3514.82.6.1007

Keyes, C. L. M., \& Simoes, E. J. (2012). To flourish or not: Positive mental health and all-cause mortality. American Journal of Public Health, 102(11), 2164-2172. https://doi.org/10.2105/AJPH.2012.300918

Kins, E., \& Beyers, W. (2010). Failure to launch, failure to achieve criteria for adulthood? Journal of Adolescent Research, 25(5), 743-777. https://doi.org/10.1177/0743558410371126

Lamers, S. M. a, Westerhof, G. J., Kovács, V., \& Bohlmeijer, E. T. (2012). Differential relationships in the association of the Big Five personality traits with positive mental health and psychopathology. Journal of Research in Personality, 46(5), 517-524. https://doi.org/10.1016/j.jrp.2012.05.012

Lee, C.-Y. S., \& Goldstein, S. E. (2016). Loneliness, Stress, and Social Support in Young Adulthood: Does the Source of Support Matter? Journal of Youth and Adolescence, 45(3), 568-580. https://doi.org/10.1007/s10964-015-0395-9

Leftkowitz, E. S., \& Gillen, M. M. (2006). “'Sex is just a normal part of life"': Sexuality in emerging adulthood. In J. L. Tanner \& J. J. Arnett (Eds.), Emerging adults in America: Coming of age in the 21st century. (pp. 235-256). Washington, DC, US: American Psychological Association. https://doi.org/http://dx.doi.org/10.1037/11381-010

Lehnart, J., Neyer, F. J., \& Eccles, J. (2010). Long-Term Effects of Social Investment: The Case of Partnering in Young Adulthood. Journal of Personality, 78(2), 639-670. https://doi.org/10.1111/j.1467-6494.2010.00629.x

Lucas, R. E., Diener, E., \& Suh, E. (1996). Discriminant validity of well-being measures. Journal of Personality and Social Psychology, 71(3), 616-628. https://doi.org/0022-3514/96/S3.00

Lyubomirsky, S., Sheldon, K. M., \& Schkade, D. (2005). Pursuing happiness: the architecture of sustainable chage. Review of General Psychology, 9(2), 1-47. https://doi.org/10.1037/10892680.9.2.111

Marosi, A., \& Velikonja, M. (2013). The gender impact of the crisis and the gap in total hours worked. Employment and Social Developments in Europe 2013. Retrieved from. http://ec.europa.eu/social/search.jsp?mainCat $=22 \&$ subCat $=\&$ policyArea $=0 \&$ policyAreaSub $=0 \&$ yea $\mathrm{r}=0 \&$ country $=0 \&$ city $=0 \& \mathrm{refNo}=\& \operatorname{advSearchKey}=+$ gender + employment + gap \& mode $=$ advancedSu bmit\&langId $=$ en\&searchType $=\&$ order $=$

Meade, A. W., Johnson, E. C., \& Braddy, P W. (2008). Power and sensitivity of alternative fit indices in tests of measurement invariance. The Journal of Applied Psychology, 93, 568-592. doi:10.1037/0021-9010.93.3.568

MECD (2015). Datos y Cifras del Sistema Universitario Español. Curso 2014/15 [Facts and Figures of the Spanish University System. Academic Year 2014/15]. Madrid: Ministerio de Educación, Cultura y Deporte. Retrieved from https://www.educacionyfp.gob.es/dms/mecd/servicios-alciudadano-mecd/estadisticas/educacion/universitaria/datos-cifras/Datos-y-Cifras-del-SUECurso-2014-2015.pdf

MECD. (2016). Datos y Cifras del Sistema Universitario Español. Curso 2015/16 [Facts and Figures of 
De la Fuente, R., Sánchez-Queija, I., Parra, A., y Lizaso, I. (2019). Flourishing during emerging adulthood from a gender perspective. Journal of Happiness Studies. doi: 10.1007/s10902-019-00204-9. In press.

the Spanish University System. Academic Year 2015-2016]. Ministry of Education, Culture and Sport. Madrid: Ministerio de Educación, Cultura y Deporte. Retrieved from http://www.mecd.gob.es/educacion-mecd/areas-educacion/universidades/estadisticasinformes/datos-cifras.html

Navarro-Guzmán, C., \& Casero-Martínez, A. (2012).Análisis de las diferencias de género en la elección de estudios universitarios [Analysis of Gender Differences in Degree Choice]. Estudios Sobre Educación, 22, 115-132.

O’Connor, M., Sanson, A., Hawkins, M. T., Letcher, P., Toumbourou, J. W., Smart, D., ... Olsson, C. A. (2011). Predictors of Positive Development in Emerging Adulthood. Journal of Youth and Adolescence, 40(7), 860-874. https://doi.org/10.1007/s10964-010-9593-7.

OECD. (2017). Education at a Glance 2017: OECD Indicators. Paris: OECD Publishing. Retrieved November 1, 2017 from http://dx.doi.org/10.1787/eag-2017-en

Orth, U., \& Robins, R. W. (2014). The Development of Self-Esteem. Current Directions in Psychological Science, 23(5), 381-387. https://doi.org/10.1177/0963721414547414

Paciello, M., Ghezzi, V., Tramontano, C., Barbaranelli, C., \& Fida, R. (2016). Self-efficacy configurations and wellbeing in the academic context: A person-centred approach. Personality and Individual Differences, 99, 16-21. https://doi.org/10.1016/j.paid.2016.04.083

Padilla-Walker, L. M., Barry, C. M. N., Carroll, J. S., Madsen, S. D., \& Nelson, L. J. (2008). Looking on the bright side: The role of identity status and gender on positive orientations during emerging adulthood. Journal of Adolescence, 31(4), 451-467. https://doi.org/10.1016/j.adolescence.2007.09.001

Padilla-Walker, L. M., Nelson, L. J., Carroll, J. S., \& Jensen, A. C. (2010). More than a just a game: Video game and internet use during emerging adulthood. Journal of Youth and Adolescence, 39(2), 103-113. https://doi.org/10.1007/s10964-008-9390-8

Paradise, A. W., \& Kernis, M. H. (2002). Self-esteem and Psychological Well-being: Implications of Fragile Self-esteem. Journal of Social and Clinical Psychology, 21(4), 345-361. https://doi.org/10.1521/jscp.21.4.345.22598

Petersen, A. C. (1993). Presidential address: Creating adolescents: The role of context and process in developmental trajectories. Journal of Research on Adolescence, 3(1), 1-18. http://dx.doi.org/10.1207/s15327795jra0301_1

Phan, H. P. (2016). Longitudinal examination of optimism, personal self-efficacy and student well-being: a path analysis. Social Psychology of Education, 19(2), 403-426. https://doi.org/10.1007/s11218015-9328-4

Ramírez-Maestre, C., Correa, M., Rivas, T., López-martínez, A. E., Serrano-ibáñez, E. R., \& Esteve, R. (2017). Psychometric characteristics of the Flourishing Scale-Spanish Version ( FS-SV ). The factorial structure in two samples : Students and patients with chronic pain. Personality and Individual Differences, 117, 30-36. https://doi.org/10.1016/j.paid.2017.05.035

Reifman, A., Arnett, J. J., \& Colwell, M. J. (2007). Emerging adulthood: Theory, assessment, and application. Journal of Youth Development, 2(1), 40-50. https://doi.org/10.5195/jyd.2007.359

Roberson, P. N. E., Norona, J., Bishop, J., \& Welsh, D. (2017). The Influence of Relationship Stability Patterns in Emerging Adulthood on Chronic Illness and Health Behaviors. Global Journal of 
De la Fuente, R., Sánchez-Queija, I., Parra, A., y Lizaso, I. (2019). Flourishing during emerging adulthood from a gender perspective. Journal of Happiness Studies. doi: 10.1007/s10902-019-00204-9. In press.

Human-Social Science: H Interdisciplinary, 17(7), 1-11

Ryff, C. D., \& Keyes, C. L. M. (1995). The structure of psychological well-being revisited. Journal of personality and social psychology, 69(4),719-727. https://doi.org/10.1037/0022-3514.69.4.719

Ryff, C. D., \& Singer, B. (1998). The Contours of Positive Human Health. Psychological Inquiry, 9(1), 1-28. https://doi.org/10.1207/s15327965pli0901_1

Ryff, C. D., \& Singer, B. H. (2008). Know thyself and become what you are: A eudaimonic approach to psychological well-being. Journal of happiness studies, 9(1), 13-39. https://doi.org/ 10.1007/s10902-006-9019-0

Sanchez-Bruno, A., \& Rosal, A. B. D. R. (2005). Fisher's transformation to determine confidence intervals for Pearson's product-moment correlation coefficient. Psicothema, 17(1), 148-153.

Sandvik, E., Diener, E., \& Seidlitz, L. (1993). Subjective Well- Being: The Convergence and Stability of Self- Report and Non- Self- Report Measures. Journal of Personality, 61(3), 317-342. https://doi.org/10.1111/j.1467-6494.1993.tb00283.x

Satorra, A., \& Bentler, P. M. (2001). A Scaled Difference Chi-Square Test Statistic for moment Structure Analysis. Psychometrika, 66, 507-514.

Schotanus-Dijkstra, M., Pieterse, M. E., Drossaert, C. H. C., Westerhof, G. J., de Graaf, R., ten Have, M., ... Bohlmeijer, E. T. (2016). What Factors are Associated with Flourishing? Results from a Large Representative National Sample. Journal of Happiness Studies, 17(4), 1351-1370. https://doi.org/10.1007/s10902-015-9647-3

Schulenberg, J. E., Bryant, A. L., \& O'malley, P. M. (2004). Taking hold of some kind of life: How developmental tasks relate to trajectories of well-being during the transition to adulthood. Development and Psychopathology, 16, 1119-1140. https://doi.org/10.1017/S0954579404040167

Schulenberg, J. E., Maggs, J. L., \& O’Malley, P. M. (2003). How and why the understanding of developmental continuity and discontinuity is important. In J. T. Mortimer \& M. J. Shanahan (Eds.) Handbook of the life course (pp. 413-436). Boston, MA: Springer.

Schulenberg, J. E., O’Malley, P. M., Bachman, J. G., \& Johnston, L. D. (2000). "Spread your wings and fly": The course of well-being and substance use during the transition to young adulthood. In $L$. Crockett \& R. Silbereisen (Eds.) Negotiating adolescence in times of social change (pp. 224-255). New York: Cambridge University Press.

Schulenberg, J. E., \& Zarrett, N. R. (2006). Mental Health During Emerging Adulthood: Continuity and Discontinuity in Courses, Causes, and Functions. In J. J. Arnett \& J. L. Tanner (Eds.), Emerging adults in America: Coming of age in the 21st century. (pp. 135-172). Washington: American Psychological Association. http://dx.doi.org/10.1037/11381-006

Schultz, L. H., Selman, R. L., \& LaRusso, M. D. (2003). The assessment of psychosocial maturity in children and adolescents: Implications for the evaluation of school-based character education programs. Journal of Research in Character Education, 1(2), 67-87.

Seligman, M. E. P. (2011). Flourish: A visionary new understanding of happiness and well-being. London: Brealey, Nicholas.

Seligman, M. E. P., Ernst, R. M., Gillham, J., Reivich, K., \& Linkins, M. (2009). Positive education: Positive psychology and classroom interventions. Oxford Review of Education, 35(3), 293-311. 
De la Fuente, R., Sánchez-Queija, I., Parra, A., y Lizaso, I. (2019). Flourishing during emerging adulthood from a gender perspective. Journal of Happiness Studies.

doi: 10.1007/s10902-019-00204-9. In press.

https://doi.org/10.1080/03054980902934563

Stevenson, B., \& Wolfers, J. (2009). The Paradox of Declining Female Happiness. American Economic Journal: Economic Policy, 1(2), 190-225. https://doi.org/10.1257/pol.1.2.190

Tanner, J. L., Arnett, J. J., \& Leis, J. A. (2008). Emerging Adulthood: Learning and Development During the First Stage of Adulthood. In M. C. Smith \& N. DeFrates-Densch (Eds.), Handbook of research on adult learning and development (pp. 34-67). Nueva York, NY: Routledge/Taylor \& Francis Group.

Tesch-Römer, C., Motel-Klingebiel, A., \& Tomasik, M. J. (2008). Gender differences in subjective wellbeing: Comparing societies with respect to gender equality. Social Indicators Research, 85(2), 329 349. https://doi.org/10.1007/s11205-007-9133-3

Thomas, P. A., Liu, H., Umberson, D., \& Suitor, J. J. (2017). Family Relationships and Well-Being. Innovation in Aging, 1(3), 1-11. https://doi.org/10.1093/geroni/igx025

Vázquez, C., Hervás, G., Rahona, J. J., \& Gómez, D. (2009). Psychological well-being and health. Contributions of positive psychology. Annuary of Clinical and Health Psychology, 5, 15-28.

Veenhoven, R. (1996). Developments in satisfaction-research. Social Indicators Research, 37(1), 1-46. https://doi.org/10.1007/BF00300268

Veenhoven, R. (2008). Healthy happiness: Effects of happiness on physical health and the consequences for preventive health care. Journal of Happiness Studies, 9(3), 449-469.

https://doi.org/10.1007/s10902-006-9042-1

Waterman, A. S., Schwartz, S. J., Zamboanga, B. L., Ravert, R. D., Williams, M. K., Bede Agocha, V., ... Brent Donnellan, M. (2010). The questionnaire for eudaimonic well-being: Psychometric properties, demographic comparisons, and evidence of validity. Journal of Positive Psychology, 5(1), 41-61. https://doi.org/10.1080/17439760903435208

Wilkinson, L., \& Wilkinson and the APA Task Force on Statistical Inference. (1999). Statistical methods in psychology journals: Guidelines and explanations. American Psychologist, 54(8), 594-604. https://doi.org/10.1037/0003-066X.54.8.59

Xu, H., \& Tracey, T. J. G. (2017). Use of multi-group confirmatory factor analysis in examining measurement invariance in counseling psychology research. The European Journal of Counselling Psychology, 6(1), 75-82. https://doi.org/10.5964/ejcop.v6i1.120

Zimet, G. D., Dahlem, N. W., Zimet, S. G., \& Farley, G. K. (1988). The Multidimensional Scale of Perceived Social Support. Journal of Personality Assessment, 52(1), 30-41. https://doi.org/10.1207/s15327752jpa5201

Zweig, J. S. (2015). Are Women Happier than Men? Evidence from the Gallup World Poll. Journal of Happiness Studies, 16(2), 515-541. https://doi.org/10.1007/s10902-014-9521-8 